\title{
IDEA WYCHOWANIA DO POKOJU W PROGRAMACH POMOCOWYCH DZIECIOM W AFRYCE
}

\begin{abstract}
Streszczenie: Ludzkością od wieków targają różnego rodzaju spory, konflikty, wojny. Współczesny świat również nie jest wolny od różnych napięć, które często nabrzmiewają do tego stopnia, że później przeradzają się w otwarty konflikt zbrojny. Życie człowieka, jego rozwój i los cywilizacji zależą od umocnienia i zagwarantowania pokoju na świecie. W tym kontekście szczególne znaczenie ma edukacja na rzecz pokoju czy też wychowanie do pokoju, wzajemnego porozumienia i poszanowania godności każdego człowieka. Największymi ofiarami wojny są zawsze dzieci i to właśnie one potrzebują szczególnej pomocy w rozwoju. W kierowanych do nich programach pomocowych powinna zawierać się idea wychowania do pokoju, tak aby kształtować w młodym pokoleniu postawy: szacunku dla drugiego człowieka, wartości życia, altruizmu, empatii.
\end{abstract}

Słowa kluczowe: pokój, wychowanie do pokoju, edukacja na rzecz pokoju, ludobójstwo, pomoc rozwojowa.

\section{Wstęp}

Wiek XX za sprawą Ellen Key został w pedagogice ogłoszony wiekiem dziecka. Jak podkreśla Barbara Smolińska-Theiss, książka E. Key Stulecie dziecka była odkryciem dziecka, stała się zapowiedzią, że XX wiek stworzy dzieciom warunki do wydobycia z nich tego, co najlepsze, że wskaże drogę, jak od najmłodszych lat kształtować ludzki rozum, dobro i wolę, dzięki którym będzie możliwe zbudowanie mądrzejszego i lepszego świata. Nie spełniły się jednak nadzieje szwedzkiej sufrażystki, że dzieci potrafią zmienić bieg historii XX wieku, ale też nie podważyło to nadziei, jaką dorośli obdarzyli dzieci. Świat dorosłych dowartościował dzieci, nadając im prawa potwierdzone międzynarodowymi aktami. Niemniej jednak „[w]iek XX zniewolił także dziecko, wciągnął je w wojnę. Stało się ono ofiarą wojen. Ginęło razem z ludnością cywilną, znosiło głód i poniewierkę. Opętańcze systemy wydały wyroki śmierci na dzieci żydowskie, słowiańskie. Wyniszczenie dzieci miało prowadzić do wyniszczenia narodów" (Smolińska-Theiss 1999, s. 8). 
Paradoksalnie wiek, który miał być wiekiem dziecka, stał się wiekiem, w którym wojna i przemoc rozciągnęły się na codzienne życie dziecka.

\section{Wychowanie do pokoju}

Przyszłość świata w dużej mierze zależy od konsekwentnej obrony pokoju, jak również od sprawiedliwej realizacji nowego porządku społecznego i ekonomicznego. Tak samo ważnym elementem utrzymania pokoju na świecie jest edukacja. Ponieważ edukacja pozwala zrozumieć charakter, złożoność i tendencje rozwojowe współczesnego świata oraz, co istotne, kierować tym rozwojem. Trzeba zatem poszukiwać nowych teorii i skutecznych praktyk edukacyjnych rozumianych w kategoriach dobra społecznego, które mogłyby przyczynić się do wzajemnego zrozumienia.

Podejmując próbę analizy idei wychowania do pokoju, obecnej w programach pomocowych, które służą jako wsparcie dziecka w rozwoju, należy odnieść się do terminologii z tego zakresu. Za Haliną Gajdamowicz przyjmuję tu pojęcie „wychowanie do pokoju”, chociaż w literaturze przedmiotu spotykamy się również z takimi pojęciami, jak „wychowanie dla pokoju” czy „edukacja na rzecz pokoju” (Gajdamowicz 1997, s. 77). Warto w tym miejscu przywołać również pojęcie „pedagogiki pokoju" o szerokim znaczeniu, obejmującym zagadnienia teorii i praktyki edukacyjnej. Jako pierwszy użył tego pojęcia papież Paweł VI w 1969 roku, a następnie rozpowszechniło się ono dzięki staraniom UNESCO.

W Polsce pierwsze definicje „pedagogiki pokoju” zostały sformułowane przez Bogdana Suchodolskiego, Irenę Wojnar, Eugenię Annę Wesołowską czy Halinę Gajdamowicz w latach 8o. i 9o. ubiegłego wieku. Joanna Leek zauważa, że szczególnym zaangażowaniem na rzecz pokoju wyróżniają się organizacje, takie jak UNESCO i UNICEF. Edukacja na rzecz pokoju w rozumieniu UNESCO to przede wszystkim aktywność ukierunkowana na promowanie kultury pokoju. Pokój jest tu wartością, którą trzeba przekazywać dzieciom i młodzieży, kształtując w nich postawy i zachowania wspierające pokój, uczyć sposobów rozwiązywania konfliktów na drodze dialogu, porozumienia, bez odwoływania się do przemocy (Leek 2014, s. 249; UNESCO 2002). UNICEF natomiast formułując definicję wychowania do pokoju, mówi o procesie promowania wiedzy, umiejętności, postaw, jak też wartości niezbędnych do wywoływania zmiany w zachowaniu, które dadzą młodemu pokoleniu oraz dorosłym możliwość zapobiegania konfliktom i przemocy. Chodzi zatem o to, aby pokojowo rozwiązywać konflikty i kreować sprzyjające warunki dla zapanowania pokoju na płaszczyźnie zarówno międzyludzkiej, jak i międzynarodowej (Leek 2014, s. 249; Fountain 1999, s. 1).

W świetle powyższych ustaleń terminologicznych warto jeszcze wyjaśnić pojęcie pokojowego rozwoju dziecka. Posłużę się tu koncepcją autorstwa Katarzyny Olbrycht, która wyjaśnia pojęcie „sytuacji pokojowego rozwoju dziecka”. Autorka przyjmując perspektywę personalizmu chrześcijańskiego i odwołując się do 
Powszechnej deklaracji praw człowieka, przyjętej przez międzynarodową społeczność, w dużym stopniu inspirowaną przez Jacquesa Maritaina, przedstawia rozwój człowieka jako osoby. Rozwojowe stają się zatem te zmiany, które sprzyjają wzmacnianiu poczucia własnej godności, wolności i rozumności, odpowiedzialności za rozpoznane wartości ludzkie, zmiany pogłębiające zdolność do miłości, rozumianej jako dobrowolny dar z samego siebie dla drugiego człowieka, jak też twórczego i aktywnego uczestnictwa we wspólnocie. „Sytuacje wspomagające rozwój dziecka będą konsekwentnie rozumiane jako sytuacje (układ warunków bodźcowy i zadaniowy) wspierające jego rozwój osobowy. Wyjaśnienia wymaga jednak wyróżnik «pokojowe». Należy go rozumieć jako warunki rozwoju w pokoju i do pokoju" (Olbrycht 1999, s. 70-71; Wojtyła 1969).

K. Olbrycht, podobnie jak Jan Paweł II, pojęcie pokoju rozumie szerzej niż jako zwykły brak wojny. Tłumaczy go jako stan odczuwalnego i realnie przeżywanego bezpieczeństwa. Norweski badacz problematyki pokoju John Galtung (założyciel Peace Research Institute w Oslo) akcentował tezę, iż pokój należy rozumieć w kategorii procesu, a nie faktu. Proces zaś oznaczać tu będzie dokonywanie różnorodnych zmian, zarówno na płaszczyźnie stosunków międzynarodowych, jak i struktur społecznych poszczególnych państw. Budowanie pokoju, zdaniem autora, powinno z jednej strony prowadzić do wyeliminowania ze stosunków społecznych różnego rodzaju przejawów przemocy (strukturalnej i personalnej), a z drugiej strony do tworzenia takich warunków życia, które będą sprzyjać zaspokajaniu ludzkich potrzeb (Galtung 1975). Takie działanie prowadzić ma do budowania w społeczeństwie poczucia bezpieczeństwa, co jest jedną z fundamentalnych potrzeb człowieka, a jej zaspokojenie jest warunkiem rozwoju fizycznego, psychicznego i prawidłowego funkcjonowania jednostki w społeczeństwie. W świetle rozwoju osobowego poczucie bezpieczeństwa jest warunkiem funkcjonowania człowieka jako osoby we wszystkich wymiarach. Brak pokoju w życiu człowieka, a zwłaszcza dziecka powoduje to, że przejawia ono mniejszą odporność fizyczną i psychiczną (emocjonalną), mniejszą możliwość intelektualnego ogarnięcia sytuacji trudnych, bolesnych, czyli jest czynnikiem destrukcyjnym we wszystkich aspektach jego życia. Trudności zewnętrzne i wewnętrzne stają się wówczas dla dziecka przyczyną różnorodnych cierpień, z którymi należy nauczyć się żyć, ponieważ są w dużym stopniu niezależne od dotkniętego nimi człowieka.

\section{Wychowanie do pokoju w optyce pedagogiki społecznej}

Istnieje silny związek idei wychowania do pokoju z troską pedagogów społecznych o sytuację dziecka. Wiesław Theiss posługuje się pojęciem „zniewolone dzieciństwo", które pozwala dostrzec, wyodrębnić oraz opisać proces socjalizacji i wychowania, realizowany w sytuacji skrajnych wydarzeń społeczno-politycznych. Poszerza wiedzę na ten temat, o zakresie, treściach, formach i skutkach wychowania oraz socjalizacji. Pozwala też zaobserwować udział zagrożeń (niebezpieczeństw, 
lęków, krzywd) w powstawaniu np. hierarchii wartości, stosunku wobec otoczenia czy w kształtowaniu się programów życiowych (Theiss 1999, s. 201-202). Autor przekonuje, że niektóre sytuacje życiowe niekorzystnie wpływają na rozwój młodego pokolenia, a są to przede wszystkim sytuacje skrajne, takie jak: wojna, rozruchy społeczne, gwałtowna zmiana społeczna czy też przemoc ideologiczna. „Zrozumiałe, iż taki stan zagraża zwłaszcza najsłabszym - dzieciom i młodzieży. Z jednej strony skrajne sytuacje społeczne hamują i zniekształcają rozwój psychiczny dzieci, ich życie intelektualne, dyspozycje moralne, emocje i wolę. $Z$ drugiej - prowadzą do trwałych wypaczeń $w$ rozwoju fizycznym, grożą utratą zdrowia, a nawet pozbawieniem życia" (Theiss 1996, s. 7). W optyce edukacyjno-kulturowej zniewolone dzieciństwo jest efektem zła społecznego. Kreatorem zła społecznego, a w konsekwencji zniewolonego dzieciństwa jest zawsze człowiek, który zawsze występuje przeciwko drugiemu człowiekowi. W imię określonych idei tworzy on system instytucji i środków przemocy, uruchamia machinę zła, która na różne sposoby niszczy jego samego i jego otoczenie (Theiss 1999, s. 202-203). Trzeba jednak dodać, że zniewolone dzieciństwo ma także inną stronę; uruchamia siły ludzkie gotowe przeciwstawiać się złu społecznemu oraz nieść pomoc poszkodowanym i pokrzywdzonym, zwłaszcza dzieciom i młodzieży.

Czy istnieje jednak związek pomiędzy opieką, pomocą, wsparciem w rozwoju a wychowaniem do pokoju? W jaki sposób działalność pomocowa czy opiekuńcza mogą przyczynić się do kształtowania postawy pokoju? Przykładem może być Matka Teresa z Kalkuty, która za swoją pracę, właśnie pomocową, opiekuńczą, dobroczynną, otrzymała Pokojową Nagrodę Nobla. Trudno wyobrazić sobie realizację celów i zadań pomocowych czy opiekuńczych bez świadomych zabiegów zmierzających do określonego kształtowania osobowości podopiecznego. Przypomina o tym Helena Radlińska, gdy mówi: „we wszystkich czynnościach opiekuńczych odbywa się akt wychowawczy" (Radlińska 1961, s. 324). Relacje i zależności pomiędzy pomocą i opieką a wychowaniem poruszało wielu badaczy, zwłaszcza z zakresu pedagogiki opiekuńczej, m.in. Albin Kelm, Irena Jundziłł, Jerzy Wołczyk, Janina Maciaszkowa, Zdzisław Dąbrowski i inni. A. Kelm pisze: „Wszelkie działania opiekuńcze w stosunku do dziecka powinny sprzyjać procesowi wychowania, inaczej bowiem nie usuwają, lecz potęgują sytuacje zagrożenia i stają w sprzeczności Z istotą opieki, a więc tracą charakter opiekuńczy" (Kelm 1983, s. 13). Z pedagogicznego punktu widzenia zarówno pomoc, jak i opieka powinny prowadzić do wszechstronnego rozwoju człowieka. Kategorię rozwoju będziemy tu rozumieć jako ukierunkowany proces zmian realizowany przez określone fazy i etapy do osiągnięcia wyższych form strukturalnych i funkcjonalnych. Inaczej mówiąc, rozwój jest przejawem zmiany skierowanej na zwiększanie efektywności działań człowieka we wszystkich obszarach życiowej aktywności. Ewa Marynowicz-Hetka stwierdza, $\dot{z}$ „,w pedagogice społecznej pojęcie rozwoju rozpatrywane jest z punktu widzenia zespołu usytuowanych konkretnie czynności, podejmowanych w środowisku życia jednostki przez wychowawcę, pracownika społecznego, pedagoga społecznego, 
składających się na działanie społeczno-wychowawcze, zorientowane w kierunku wspierania, wzbogacania i w konsekwencji optymalizacji rozwoju indywidualnego jednostki oraz jej środowiska życia" (Marynowicz-Hetka 2009, s. 134).

K. Olbrycht zwraca uwagę na jeszcze jeden ważny aspekt działań pomocowych i opiekuńczo-wychowawczych, że wychowanie do wartości (np. miłości bliźniego, altruizmu, szacunku, przebaczenia) musi uwzględniać wymagania stawiane konsekwentnie, systematycznie, i co istotne, z miłością. Wśród wielu wychowawców panuje nieuzasadnione przekonanie, że stawianie dziecku wymagań może wywoływać w nim negatywne przeżycia, zaburzające jego rozwój. Tymczasem, jak przekonuje autorka, rzetelna wiedza z zakresu psychologii rozwojowej wskazuje ponad wszelką wątpliwość, że rozwój wymaga stawiania przed dzieckiem trudnych zadań, które uczy je ich podejmowania i rozwiązywania, przy wsparciu dorosłych. Wychowanie bez wymagań, w początkowej fazie zewnętrznych, a następnie stopniowo uwewnętrznionych, nie jest wychowaniem do pokoju, lecz przeciwnie prowokowaniem sytuacji konfliktowych, a także wyuczaniem postaw bezradności życiowej wobec własnych emocji i słabości charakteru (Olbrycht, s. 78).

Takie podejście bezpośrednio koresponduje z poglądami wybitnych pedagogów, przede wszystkim twórców pedagogiki opiekuńczej. Kazimierz Jeżewski krytykowany był z tego powodu, iż niekiedy oczekiwał od swoich wychowanków zwrotu otrzymanych świadczeń. Poprzez tak rozumianą pracę opiekuńczą kształtował u dzieci i młodzieży moralną zasadę: „,daję, abyś dawał”. Innymi słowy, pomagam ci teraz w takim celu, abyś sam sobie poradził, a w przyszłości byś także pomagał innym. Z etycznego punktu widzenia zasada ta ukazuje ważny postulat odnoszący się do działalności opiekuńczej i pomocowej w ogóle. Z jednej strony podkreśla wewnętrzną i naturalną potrzebę człowieka do niesienia pomocy ludziom potrzebującym, a z drugiej strony wydobywa opiekę z jej jałmużniczego charakteru, którym jest nasycona działalność pomocowa, rozumiana jako czyny miłosierdzia. Opieka wychowawcza, jak przekonuje A. Kelm, stymuluje „poczucie wzajemnej powinności moralnej. I nie jest sprawą przypadku, że u osób, które otrzymały w młodości takie właśnie wychowawczo-opiekuńcze wsparcie, ukształtowała się silna postawa opiekuńcza, skłaniająca do podjęcia trudu opieki nad innymi. Taka była m.in. droga do działalności opiekuńczo-wychowawczej Dziadka - Kazimierza Lisieckiego, wychowanka, a następnie wychowawcy w bursie prowadzonej przez Józefa Czesława Babickiego" (Kelm 2000, s. 97).

Agnieszka Piejka zauważa, że w odniesieniu do relacji człowiek-świat na płaszczyźnie edukacji dla pokoju pojawiają się liczne wątki i problemy. Podstawowe pytanie dotyczy sposobu rozwijania $\mathrm{w}$ jednostce poczucia odpowiedzialności i sprawczości pokoju na świecie. Poszukiwanie odpowiedzi na to pytanie dokonuje się także w obszarze pedagogiki społecznej oraz edukacji wielokulturowej i międzykulturowej, ponieważ współczesnego świata nie da się dziś zrozumieć bez odniesienia do jego wielokulturowego wymiaru. Przy okazji różnorodnych inicjatyw promujących ideę pokoju coraz częściej przywoływana jest kategoria 
„kultury pokoju”. Jeśli zatem, zastanawia się dalej autorka, kształtowanie kultury pokoju jest tak ważnym zobowiązaniem edukacyjnym, to obliguje wszystkich ludzi do zadawania pytań o konkretne możliwości jego realizacji. Należy jednak uwzględnić wielość perspektyw, istotnych w tym względzie, „od perspektywy najmniejszych społeczności, będących pierwszym środowiskiem wychowawczym dziecka, przez poszerzające się w toku jego życia obszary społecznego uczestnictwa (grupy rówieśnicze, małe ojczyzny, instytucje oświatowe i religijne), do perspektywy kontynentalnej i globalnej, kiedy to człowiek postrzegany jest jako przedstawiciel wielkiej, ludzkiej wspólnoty istot zamieszkujących Ziemię. Każda z tych perspektyw jest istotna dla kształtowania się tożsamości człowieka" (Piejka 2015, s. 123). Zadaniem pedagogiki staje się stworzenie pewnej przestrzeni, aby proces kształtowania kultury pokoju człowiek realizował w sobie od dzieciństwa.

\section{Dobra praktyka idei wychowania do pokoju}

Jeśli wychowanie do pokoju jest promowaniem wiedzy, umiejętności, postaw i wartości niezbędnych do wywoływania zmian w zachowaniu dzieci i młodzieży, to wywołuje to rozmaite implikacje praktyczne, także dla działalności wychowawczej. Jedną z propozycji godnych zauważenia jest program edukacyjny o nazwie "Gen pokoju”. Autorka tego programu, Agnieszka Uniewska, wskazuje, że odnosi się on do wzajemnej opieki, wychowania i złożonego procesu socjalizacji oraz inkulturacji. Związany jest $\mathrm{z}$ wiarą $\mathrm{w}$ dobroć i szlachetność, które człowiek posiada w sobie i które trzeba pielęgnować i wzmacniać od wczesnego dzieciństwa, kreując optymalne warunki rozwoju. A. Uniewska odwołując się do poglądów Alberta Bandury i Richarda Waltersa, którzy uważali, że agresja jest wyuczonym sposobem zachowania się, radzenia sobie w życiu i przezwyciężania życiowych przeszkód, utrudniających bądź uniemożliwiających osiągnięcie wyznaczonego sobie celu. W związku z tym, jeśli reagujemy agresywnie, oznacza to, że takie sposoby działania utrwaliły się w naszej pamięci jako skuteczne oraz takie też wzory zachowań zostały przez nas przyswojone w procesie socjalizacji, które oferowało nam nasze środowisko społeczne. Oznacza to dalej, że jeśli można nauczyć się zachowań agresywnych, to możliwe jest także ich oduczenie i uświadomienie sobie, z jakich powodów droga przemocy i zła nie jest dla człowieka rozwiązaniem konstruktywnym, lecz ma charakter destrukcyjny i prowadzi donikąd (Uniewska 2003, s. 548; Bandura, Walters 1968).

Zasadniczym celem programu jest rozwijanie wyobraźni moralnej dzieci i młodzieży oraz ukształtowanie w ich świadomości przekonania, iż naruszanie godności, przekraczanie granic nietykalności cielesnej nie jest i nie może być bezkarne. Ponadto należy uświadomić im, że nikt nie jest agresywny dopóty, dopóki sam nie da sobie do tego prawa, a tego uczynić nie może. Niniejszy program służy przede wszystkim młodemu pokoleniu wzrastać do bycia człowiekiem dobrym dla siebie i dla innych, który ludzkie życie, godność osoby i pokój uzna za wartości najwyższe, 
ponadczasowe i autoteliczne. Ma być także pomocą dla nauczycieli i wychowawców, którzy pragną „towarzyszyć w tym procesie swoim uczniom, kształtować w nich przekonanie o konieczności życia według niepodważalnych zasad moralnych, wzbudzić potrzebę stworzenia własnego systemu norm i wartości, na którym powinno opierać się ich życie. Systemu, w którym takie pojęcia, jak: szacunek dla prawa i człowieka, dialog i tolerancja, pojednanie, współistnienie czy zdrowy altruizm nie są tylko pusto brzmiącymi hasłami, lecz autentycznymi drogowskazami w labiryncie otaczającej rzeczywistości” (Uniewska, s. 549).

Umiejętność pokojowego i konstruktywnego współżycia z drugim człowiekiem wyznacza tu kierunek działań edukacyjnych, które opierają się na trzech filarach. Program edukacyjny „Gen pokoju”, jako propozycja wychowania do pokoju, zawiera trzy bloki tematyczne:

1) „Do czego człowiek ma prawo w świetle prawa?” - obejmuje podstawową wiedzę na temat prawa, jego funkcji spełnianych w życiu społecznym oraz relacji między prawem a innymi systemami kontroli. Zawiera treści odnoszące się do podstawowych praw i wolności człowieka, zagwarantowanych w międzynarodowych aktach prawnych;

2) „Wychowanie do Pokoju - Wychowaniem do Dialogu” - w całości poświęcony jest zagadnieniu komunikacji międzyludzkiej. Tematyka poszczególnych zajęć obejmuje ważne z punktu widzenia współżycia społecznego problemy komunikacji: rolę języka w procesie poznania i autokreacji, zjawisko determinizmu językowego i jego wpływ na postrzeganie otaczającej człowieka rzeczywistości oraz stosunek do niej;

3) „Wychowanie jako wybór wartości” - stanowi cykl wykładów na temat systemu wartości i jego znaczenia w życiu człowieka, ze szczególnym uwzględnieniem wartości ludzkiego życia, zdrowia, godności i spokoju jako wartości autotelicznych. W tym bloku tematycznym poruszane są następujące zagadnienia szczegółowe:

- człowiek i jego dobro;

- świadomość silnych wzajemnych korelacji między ładem wewnętrznym człowieka a pokojem tworzonym przez niego wokół siebie;

- pojednanie współistnienia, tzn. sztuka życia w zgodzie z własnymi przekonaniami i aspiracjami;

- kształtowanie i rozwój inteligencji emocjonalnej, tzn. umiejętność rozpoznawania i nazywania własnych uczuć i emocji;

- zdrowy altruizm jako efekt wychowania dla dobra, tzn. wzmacnianie motywacji do działań godnych człowieka - troski o dobro drugiego człowieka, życzliwość i wrażliwość na krzywdę, uczciwość i tolerancja (Uniewska, s. 550-552).

Program „Gen pokoju” jako konkretna propozycja idei wychowania do pokoju stara się prowadzić wychowanka do dojrzałej odpowiedzialności za siebie i innych, uczyć młodego człowieka wrażliwości na wspólnotę ludzkiego losu oraz rozbudzać w nim poczucie jedności z ludźmi potrzebującymi na całym świecie. Program odwołuje się do wartości uniwersalnych, opartych na pojęciu dobra, i jest zakorzeniony w tradycji głębokiego humanizmu. 
W podobnym tonie wypowiadała się jedna z pionierek wychowania do pokoju, Maria Montessori, wskazując na potrzebę rozwijania w dziecku umiejętności współpracy, pokojowego rozwiązywania konfliktów, chęci dzielenia się z innymi, dobrze pojętą litość wobec słabszych oraz szacunek do człowieka (ludzkości), do jego osiągnięć i sił twórczych. Pisała bowiem: „Bycie człowiekiem daje tak wiele powodów do dumy, że powinno prowadzić do poczucia odpowiedzialności i (prawie) religijnego uwielbienia. Ten, kto osiąga taki stan, szanuje i chroni nie tylko życie ludzkie, ale też wszystkie istniejące rzeczy, gdyż z nich wszystkich człowiek czerpie wielkość własnych dzieł" (Montessori 2009, s. 185). Autorka teorii i praktyki wychowania przedszkolnego nie tylko przekonuje o konieczności kreowania relacji człowiek-świat od najwcześniejszego etapu edukacji, ale widzi także potrzebę kształtowania u dziecka sfery uczuć, wyobraźni, intuicji i empatii.

Czy jednak pokój w danym państwie (społeczeństwie), a tym bardziej na świecie może zależeć od pojedynczego człowieka? Próbą odpowiedzi na to pytanie może być stwierdzenie zawarte w preambule aktu konstytutywnego UNESCO z 1945 roku. W dokumencie czytamy: „Skoro wojny biorą początek w umysłach ludzi, to właśnie w umysłach ludzi muszą być budowane podstawy pokoju" (http://www. unesco.pl). Oznacza to, że problemy pokoju i wojny mają swoje źródło w wyborach i działaniach konkretnych ludzi. Dlatego też w przytoczonym dokumencie zostało podkreślone, że oprócz działań politycznych, które koncentrują się na polepszeniu stosunków międzynarodowych oraz wyeliminowaniu licznych lokalnych konfliktów, podstawowym zadaniem człowieka jest budowanie pokoju przez edukację. Problem pokoju staje się problemem pedagogicznym, gdyby tak nie było, pokój oznaczałby dłuższą lub krótszą przerwę pomiędzy wojnami i mniejszymi konfliktami zbrojnymi.

\section{Ludobójstwo w Rwandzie}

Pod koniec XX wieku miało miejsce ludobójstwo w Rwandzie. Konflikt o podłożu etnicznym (plemię Hutu przystąpiło do całkowitej eksterminacji plemienia Tutsi) wybuchł 7 kwietnia 1994 roku i trwał trzy miesiące. Szacuje się, że pochłonął on ok. mln ofiar. Dla podkreślenia rozmiarów tragedii, jaka miała miejsce w Rwandzie, dostępne są dane, z których wynika, że w czasie ludobójstwa statystycznie zabijano ponad 10 tys. osób dziennie (Genocide 2004, s. 22). Najboleśniejszym jednak problemem był los dzieci w czasie ludobójstwa. Dzieci Tutsi zabijano razem z ich rodzicami. Te zaś, które przeżyły (dostępne opracowania podają liczbę ok. 500 tys. sierot), doznały głębokiej traumy. W kwietniu 1995 roku w mieście Nyamata $\mathrm{z}$ ramienia UNICEF-u zostały przeprowadzone badania wśród dzieci od 5 do 15 roku życia. Badaniem objęto 207 dzieci. Dotyczyło ono ich przeżyć z czasu wojny. Oto niektóre wyniki tego badania:

- 55,6 proc. dzieci przeżyło zabójstwo swoich rodziców;

- 74,9 peoc. dzieci widziało zabijanie innych ludzi; 
- 94,5 proc. dzieci widziało zwłoki zabitych;

- 70,8 proc. dzieci doświadczyło zagrożenia życia;

- 67,6 proc. dzieci było świadkiem zniszczenia własnego domu;

$-58,5$ proc. dzieci było maltretowanych przez uzbrojonych ludzi;

$-79,7$ proc. dzieci słyszało krzyki umierających;

- 62,8 proc. dzieci słyszało błagania ludzi o ratunek (Pałyga 1998, s. 128).

Dla takich dzieci, z ramienia programu UNICEF-u pt. „Pomoc dzieciom traumatycznym - zranionym, urazowym", zorganizowano pomoc terapeutyczną. Pomocy udzielali także dwaj polscy misjonarze: ks. Zenon Bazan (pallotyn) i ks. Zdzisław Żywica (karmelita), którzy zostali do tego odpowiednio przygotowani oraz wspierani przez Instytut Formacji Ludzkiej w Montrealu (Babicki 2013, s. 94). Nie mniejszym problemem dla rwandyjskiego społeczeństwa pozostała kwestia zdewastowanej psychiki dzieci - sprawców morderstw. Więzienia były pełne młodocianych uczestników ludobójstwa, umieszczanych tam wspólnie z dorosłymi mordercami. Jeszcze w 2006 roku z okazji Dnia Afrykańskiego Dziecka UNICEF wynegocjował z władzami Rwandy uwolnienie z więzień ok. 600 dzieci, które w czasie ludobójstwa nie ukończyły 14 roku życia (Pałyga 1998, s. 124).

Jan Paweł II dopełnił ten obraz przedstawiający sytuację dzieci w Rwandzie po ludobójstwie szerszym kontekstem: „Oprócz dzieci zamordowanych chcę też wspomnieć dzieci trwale okaleczone podczas działań wojennych lub po ich zakończeniu. Myślę tu także o dzieciach prześladowanych, gwałconych i zabijanych podczas tak zwanych czystek etnicznych. Dzieci są nie tylko ofiarami wojennej przemocy, wiele $\mathrm{z}$ nich jest zmuszanych do czynnego uczestnictwa w wojnie. W niektórych krajach świata dochodzi do tego, że chłopcy i dziewczęta, nieraz bardzo młodzi, są przymuszani do służby w formacjach wojskowych walczących stron" (Jan Paweł II 1999, s. 12). Papież przekonywał, że przeciwieństwem wojny nie jest wolność, lecz pokój, i apelował do świata dorosłych, aby zapewnił dzieciom pokój - taki, który wyrasta z praw dziecka i miłości do dzieci. Na gruncie takiego pokoju dorośli są zobligowani zbudować dzieciom odpowiednią przestrzeń do godnego życia, wszechstronnego rozwoju, nauki i wchodzenia w dorosłość, biorąc za to odpowiedzialność.

Analizując sytuację dzieci w Rwandzie po ludobójstwie, można dostrzec czynniki konstytuujące kategorię zniewolonego dzieciństwa. W czasie trwania ludobójstwa życie i zdrowie dzieci było bezpośrednio zagrożone. Na co dzień przeżywały uczucia lęku, strachu o życie swoje i bliskich. Natomiast obrazy bestialskich zbrodni, które działy się na ich oczach, spowodowały zaburzenie prawidłowego rozwoju psychicznego, zniekształciły ich życie intelektualne, wypaczyły dyspozycje moralne, emocje i wolę. Z tych przeżyć wyłania się obraz „naznaczonego dzieciństwa”. Ich dzieciństwo zostało naznaczone głęboką traumą, bólem i cierpieniem, zarówno tym fizycznym, jak i tym psychicznym.

Paradoksalnie dla wielu dzieci podczas krwawych walk jedynym bezpiecznym miejscem w ich ocenie było wojsko. Wszystkie one noszą widoczne i trwałe ślady okaleczeń fizycznych i psychicznych. Rwandyjskie społeczeństwo nigdy wcześniej 
nie spotkało się z podobnym zjawiskiem na taką skalę. Jedno z ogromnych problemów stanowiły dzieci bezimienne, pozbawione własnej tożsamości. Z punktu widzenia administracji praktycznie nie istniały, nie mogły więc liczyć na urzędową pomoc. To właśnie te dzieci były najbardziej narażone na wykorzystywanie i wszelkiego rodzaju nadużycia (Szczodrowski 2007, s. 91). Bezimienne dzieci stanowiły największą część dzieci ulicy, nazywano je mayibobo lub saligoma, tzn. „żyjące poza jakąkolwiek strukturą rodzinną”, czy też szerzej, „społeczną”. Dzieci mayibobo, osierocone, pozbawione tożsamości, nękane przez skrajną biedę, żyjące w poczuciu osamotnienia i z brakiem zainteresowania ze strony władz, wykorzystywane w nieludzki sposób, stanowiły znaczną część rwandyjskiego społeczeństwa. Ich domem była ulica lub targowisko, gdzie szukały pożywienia, a żywiły się tym, co ukradły lub znalazły na śmietniku. Spośród nich tworzyły się uliczne gangi, dziecięce i młodzieżowe (Petrykiewicz 2004, s. 5).

Jako ilustrację do tej sytuacji przywołam opis spotkania z jednym $\mathrm{z}$ misjonarzy, pracującym z dziećmi ulicy w Rwandzie: „Padri - zwrócił się do mnie drżącym głosem Marek. Oni wszyscy są sierotami. Rodziców zamordowano im w czasie walk w 1994 roku. Jego mama i ojciec - wskazał na jednego z chłopców - chyba żyją, tak mówi ciotka, ale uciekli do Zairu. Od roku nie dają znaku życia. Żaden chłopiec nie chodzi do szkoły. Nie mają domów; albo mieszkają w nich obcy ludzie. Chłopcy śpią pod schodami tego kościoła - ruchem ręki wskazał nasz kościół parafialny. - Reszta śpi na bazarze. Przykrywają się starymi kartonami..." (Rusinek 2003, s. 40-41). Dla tych dzieci „szkołą” jest ulica, na której uczą się kradzieży, picia alkoholu, współżycia seksualnego; są wykorzystywane jako dilerzy narkotyków i zmusza się je do prostytucji (Bahisha 1998). Przywołane tu przykłady są tylko znikomym obrazem „naznaczonego dzieciństwa”, którego inne wymiary zostały opisane w wielu pracach naukowych (Bar 2013) oraz opracowaniach autobiograficznych (Ilibagiza 2010a; Ilibagiza 2010b).

W obliczu takich ran, zarówno fizycznych, jak i psychicznych, pomoc dzieciom jest bardzo skomplikowana. Zatem jak im pomagać, aby przezwyciężając traumę, mogły się prawidłowo rozwijać i nie przekazywać tej traumy dalszym pokoleniom?

Po zakończeniu walk do Rwandy zaczęła napływać międzynarodowa pomoc. Powstawały różne programy pomocowe. Jedną z inicjatyw było zainicjowanie ruchu na rzecz dzieci w Afryce, który konkretyzował się w kilku etapach. Pierwszym etapem było założenie Ruchu Solidarności z Ubogimi Trzeciego Świata MAITRI, na podstawie którego powstała idea programu pomocowego „Adopcja Serca”. Z czasem wypracowano formę współpracy oraz zobowiązania finansowe dla rodzin adopcyjnych w Polsce, które obecnie wynoszą 15 euro + 1 euro na obsługę projektu. W ramach adopcji serca działaniami pomocowymi objęto trzy zasadnicze sfery rozwojowe dziecka:

1) opiekę medyczną - leczenie i dokarmianie dzieci dotkniętych problemem głodu. Z tych środków opłacane jest ubezpieczenie zdrowotne, które od kilku lat 
stało się w Rwandzie obowiązkowe, a które to bardzo często pozostaje poza możliwościami przeciętnej rodziny;

2) opiekę socjalną - obejmującą długofalową pomoc materialną oraz zapewnienie dzieciom osieroconym miejsca w rodzinach zastępczych;

3) edukację - zorganizowany fundusz stypendialny, z którego pokrywane są koszty nauki w szkole (Babicki 2011-2012; 2013, s. 95).

Działalność pomocowa czy opiekuńczo-wychowawcza wobec dzieci w Rwandzie ma na celu wsparcie ich wszechstronnego rozwoju i wytworzenie klimatu realnie przeżywanego przez nich bezpieczeństwa, jako podstawowej potrzeby człowieka. Jan Paweł II mówił: „Spokojne dzieciństwo pozwoli dzieciom patrzeć z ufnością na życie i na dzień jutrzejszy. Biada tym, którzy tłumią nich radosne porywy nadziei!” (Jan Paweł II, s. 17). Z całą pewnością kształtowanie dojrzałej osobowości dziecka, ukierunkowanej na pokojowe rozwiązywanie sytuacji konfliktowych, nie jest łatwe, ale też nie jest niemożliwe. Dlatego istnieje duża potrzeba podejmowania konkretnych działań kompensacyjnych wszędzie tam, gdzie to konieczne, ale również działań o charakterze profilaktycznym, nie tylko jako zwykłe unikanie zachowań agresywnych, lecz także jako kontrpropozycja roszczeniowego stylu życia i przekonania, że silniejszy ma zawsze rację. Celem takich przedsięwzięć jest kształtowanie moralnej wyobraźni, która pomagałaby w nabywaniu przekonania, że życie ludzkie jest najwyższą wartością, a tym samym mogłaby skutkować wzrostem dążeń do zaspokojenia potrzeby pokoju, tego wewnętrznego, jak i zewnętrznego.

Działalność pomocowa i opiekuńcza wyrasta z różnych korzeni, odwołuje się do innych założeń, tworzy własny nurt praktyki społecznej. Przywołany tu program „Adopcja Serca” bierze początek z chrześcijańskich źródeł miłości bliźniego i Bożego miłosierdzia. W rozumieniu Mieczysława Łobockiego, miłość bliźniego jest w swoim ewangelicznym aspekcie istotnym elementem miłości chrześcijańskiej, której najwyższym źródłem jest motywacja religijna. Miłość bliźniego uwidacznia wiele wspólnych cech występujących również w postawie altruizmu. Wspólnym składnikiem postawy altruizmu i miłości bliźniego jest np. troska o drugiego człowieka w różnych sferach jego życia i rozwoju oraz charakterystyczna dla tych postaw bezinteresowność. „W obu przypadkach mamy do czynienia ze zdecydowanie negatywnym stosunkiem do używania przemocy i zarazem postulatem czynnego przeciwstawiania się złu dobrem, co w szczególności uwypukla się w miłości bliźniego. Nie jest to także obce altruizmowi, chociaż na ogół w mniejszym stopniu" (Łobocki 1999, s. 212).

Autor wskazuje także na inne istotne podobieństwo między altruizmem a miłością bliźniego. Polega ono na zaangażowaniu w realizację idei dobra konkretnego człowieka, żyjącego „tu i teraz”, a nie przysłowiowego „dobra ludzkości”, które często ma charakter wizerunkowy, mający na celu usprawiedliwienie braku osobistej aktywności w niesieniu czynnej pomocy osobom potrzebującym. W związku z tym celem wychowania do altruizmu może być nie tylko rozwijanie u podopiecznych gotowości do świadczenia bezinteresownej pomocy, ale także to, aby potrafili 
oni uszanować w drugim człowieku godność osoby, a tym samym docenili wyższość osoby nad rzeczą, moralności nad techniką, miłosierdzia nad sprawiedliwością, bycia nad posiadaniem. Wówczas taki program wychowania nie będzie zbytnio odbiegał od chrześcijańskiej koncepcji miłości bliźniego (Łobocki 1999, s. 212).

Oprócz wsparcia materialnego i psychologicznego dzieci w Rwandzie, na które składa się budowanie kompetencji związanych z kulturą pokoju, potrzebna jest również pomoc duchowa, jako dopełnienie humanistycznej wizji człowieka. Wynika to $\mathrm{z}$ faktu, że ich świat wartości legł w gruzach, tak jak nie istnieją już ich domy rodzinne. Świadomość takiej pomocy jest wśród misjonarzy coraz większa, dlatego organizują oni spotkania terapeutyczne, grupy wsparcia lub rekolekcje. $\mathrm{Na}$ południu Rwandy, w miejscowości Ruhango, już od wielu lat funkcjonuje Centrum Pojednania przy Sanktuarium Bożego Miłosierdzia, którym kieruje ks. Stanisław Urbaniak (pallotyn - świadek ludobójstwa). W ośrodku prowadzone są sesje pojednania, przynoszące wewnętrzne uzdrowienia, co jest szczególnie ważne dla młodego pokolenia wchodzącego w dorosłe życie.

Stephen Smith, afrykanista pracujący dla francuskiego dziennika „Le Monde”, analizując eskalację konfliktów zbrojnych w Afryce, doszedł do dramatycznego wniosku. Pisze bowiem: „W Afryce nie ma już bitew, są jedynie masakry i nierówne walki, w których nie chodzi tylko o przełamanie oporu przeciwnika, lecz o jego całkowite unicestwienie włącznie z nieuzbrojonymi cywilami, kobietami i dziećmi" (Smith 2003, s. 136-137). Rodzi się zatem pytanie: Jak skutecznie pomagać ofiarom wojny w Rwandzie oraz w innych krajach Afryki? Szukając na to pytanie odpowiedzi, należy przede wszystkim unikać powierzchowności. Wydaje się, że trzeba m.in. sięgać do głębokiej chrześcijańskiej prawdy o naturze człowieka, w szczególności odnosi się to do dzieci, które bardzo łatwo zranić ze względu na kształtującą się w nich, niezwykle jeszcze wrażliwą osobowość, chłonną na różnego rodzaju bodźce. Lilla Danilecka, odwołując się do teorii francuskiego terapeuty i lekarza medycyny, Philippe Madre, specjalizującego się w pomocy psychologiczno-duchowej osobom, które doznały tzw. zranienia życia, proponuje drogę "towarzyszenia życiu”. Taką pomoc mogą świadczyć odpowiednio do tego przygotowani chrześcijanie. Pojęcie „towarzyszenie” jest tu użyte celowo, w odróżnieniu od terapii czy kierownictwa duchowego, ponieważ nie jest to ani jedno, ani drugie, chociaż w działaniu tym można znaleźć wspólne elementy. Towarzyszenie życiu opiera się przede wszystkim na konieczności wytworzenia odpowiedniego klimatu, w którym osoba cierpiąca obdarzy misjonarza (pomagającego) zaufaniem i otworzy się na słuchanie. Kolejnym krokiem jest doprowadzenie osoby zranionej do podjęcia decyzji o pogodzeniu się z traumatycznymi doświadczeniami swojego życia. Nie chodzi tu bynajmniej o postawę biernej rezygnacji w odniesieniu do swoich krzywd, ale o dokonanie wyboru własnego życia. Ten akt jest czymś więcej niż postawą psychiczną; ma znaczenie duchowe, nawet jeśli człowiek nie do końca to sobie uświadamia. W kolejnych etapach towarzyszenia życiu należy udzielać pomocy osobie zranionej w ponownym otwarciu się na drugiego człowieka i na Boga. 
Na tym etapie pomoc polega na „odkryciu prawdziwego sensu i wartości ludzkiego ciała oraz sensu życia z jego siłami napędowymi, które wyrywając z zablokowania, można ukierunkować ku dobru - a także z jego brakami i słabościami, które mogą stać się «dźwignią życia i ogniskami płodności»" (Danilecka 2005, s. 75; Madre 2005). W świetle tej teorii pomocy osobie z traumą, słabości i zranienia mogą stać się przestrzenią i okazją do doświadczenia daru Bożego miłosierdzia, pod warunkiem, że człowiek przyjmie prawdę o skuteczności Bożego miłosierdzia w swoim życiu.

Tak rozumiana pomoc ludziom dotkniętym traumą, zranieniami psychicznymi i duchowymi koresponduje z rozumieniem edukacji na rzecz pokoju w ujęciu Józefa Półturzyckiego, dla którego pokój jest wartością nadrzędną. W przekonaniu autora, pokój należy zaliczyć do sfery „sacrum i wartości transcendentalnych, gdyż pokój jest dobrem Boga, a Bóg jest Bogiem pokoju. Chrystus sam jest pokojem, gdyż jest On twórcą pojednania w podwójnej relacji między człowiekiem a Bogiem i nawzajem między ludźmi. Pojęcie pokoju ma więc charakter relacyjny, bo pokój jest zawsze między dwiema stronami, w relacjach już wspomnianych, między ludźmi a Bogiem, między Bogiem a człowiekiem, między ludźmi, ale także w szerszym znaczeniu między narodami. Dziełem Chrystusa jest pokój, a jego śmierć wprowadziła pokój, między Bogiem a człowiekiem" (Półturzycki 2003, s. 163). Dla J. Półturzyckiego uznanie pokoju za wartość nadrzędną jest fundamentalnym założeniem dla teorii i praktyki wychowania moralnego. Wartość pokoju jest tu ściśle związana z prawdą i dobrem, jak też łączy się z grupą wartości moralnych i społecznych.

Biorąc pod uwagę powyższe rozważania, wydaje się zasadne włączenia wyżej wymienionych aspektów w działalność pomocową programu „Adopcji Serca”. Udzielana dzieciom pomoc rozwojowa w ramach tego programu powinna kształtować w nich kulturę pokoju oraz przekazywać wiedzę o współzależnościach wiążących ludzi na całym świecie między sobą. Kultura pokoju oznacza nie tylko kompetencje poznawcze, ale również zdolność do empatii, altruizmu, tolerancji, dialogu; to umiejętność dzielenia się z drugim człowiekiem. Wychowanie do pokoju będzie zatem polegać na przekazywaniu uniwersalnych wartości i kształtowaniu trwałych postaw: poszanowaniu ludzkiej godności, otwartości na drugiego człowieka, umiejętności życia i współdziałania, dialogu, budowania cywilizacji miłości.

\section{Podsumowanie}

Przywołane w tekście sposoby pomocy dzieciom w Rwandzie dotkniętym dramatem ludobójstwa i jego rezonansu na współczesne życie młodego pokolenia obejmują różne wymiary ludzkiej egzystencji: materialny, psychologiczny i duchowy. Są to podejścia stanowiące oczywiście propozycje, jedne z wielu. Każde zgromadzenie zakonne działające na misjach stara się wypracować własną metodę pracy, mniej lub bardziej skuteczną. Wszystkie one jednak mają wspólny mianownik, którym jest chrześcijańska nadzieja na odnalezienie drogi wyjścia z trudnej sytuacji. Niesiona 
pomoc w tych wymiarach powinna jednocześnie przekładać się na kształtowanie kultury pokoju w dzieciach objętych programem „Adopcji Serca”, co oczywiście nie jest jedynym elementem edukacji dla pokoju. Bez względu jednak na skomplikowany układ czynników wpływających na obraz i efektywność edukacji dla pokoju, kształtowanie tej kultury w młodych ludziach, w tym przypadku wśród zranionych podziałami etnicznymi, pozostaje jej ważnym aspektem. Kultura pokoju jest ściśle związana z osobistym zobowiązaniem danej osoby wobec drugiego człowieka i świata, w którym on żyje, jako domu, który trzeba czynić lepszym. Koresponduje to $\mathrm{z}$ nadrzędnym pytaniem, jakie z punktu widzenia pedagogiki społecznej jest ciągle aktualne: „Czy i jak wychowanie może ulepszać świat?” (Theiss 2000, s. 24). Pomocowy program „Adopcja Serca” ma w tym względzie znaczący wkład poprzez kształtowanie kultury pokoju.

\section{Bibliografia}

Babicki Z. (2013). Sytuacja dziecka $w$ Rwandzie - zarys problematyki. „Pedagogika Społeczna", nr 1 (47), s. 85-104.

Babicki Z. (2011-2012). Badania własne (archiwum prywatne).

Bahisha T. (1998). Nasze dzieci cierpia. Kigali, 6 czerwca 1998 roku. List do S. Kuracińskiego [mps]. Archiwum Pallotyńskiego Sekretariatu Misyjnego w Ząbkach.

Bandura A., Walters R. (1968). Agresja w okresie dorastania: wpływ praktyk wychowawczych i stosunków rodzinnych. Czapów C. (tłum.). Warszawa: Państwowe Wydawnictwo Naukowe.

Bar J. (2013). Po ludobójstwie. Państwo i społeczeństwo w Rwandzie 1994-2012. Kraków: Kięgarnia Akademicka.

Dzieci głodujące i bez imienia. W: Różański J. (red.). Warszawa: Wydawnictwo Papieskich Dzieł Misyjnych.

Fountain S. (1999). Peace education in UNICEF. New York: Wydawnictwo UNICEF.

Gajdamowicz H. (1997). Pedagogika pokoju - refleksje aksjologiczno-metodologiczne. W: Ponczek E. (red.). „Biuletyn Centrum Badań nad Pokojem Uniwersytetu Łódzkiego”. Łódź: Wydawnictwo Centrum Badań nad Pokojem Uniwersytetu Łódzkiego.

Galtung J. (1975). Peace: Research-Education-Action. Essas In Peace Research, vol. 1, Copenhagen.

Genocide. (2004). Kigali Memorial Centre, komentarz do wystawy. Kigali: Aegis Trust.

Ilibagiza I. (2010a). Ocalona, aby mówić. Warszawa: Wydawnictwo Duc In Altum. Ilibagiza I. (2010b). Ocalona, aby przebaczyć. Warszawa: Wydawnictwo Duc In Altum.

Jan Paweł II (1999). Zapewnijmy dzieciom przyszłość w pokoju. Orędzie Jana Pawła II na XXIX Światowy Dzień Pokoju 1 stycznia 1996 roku. W: Pokój z dziećmi. 
Pedagogika chrześcijańska wobec zagrożeń rozwoju dziecka. Smolińska-Theiss B. (red.). Warszawa: Wydawnictwo Akademickie Żak.

Kelm A. (1983). Formy opieki nad dzieckiem w Polsce Ludowej. Warszawa: Wydawnictwa Szkolne i Pedagogiczne.

Kelm A. (200o). Węzłowe problemypedagogiki opiekuńczej. Warszawa: Wydawnictwo Akademickie Żak.

Leek, J. (2014). Pomiędzy porozumieniem a zrozumieniem. Wyzwania edukacji na rzecz pokoju. „Studia Dydaktyczne”, nr 26, s. 247-257.

Łobocki M. (1999). Metody wychowania do altruizmu. W: Smolińska-Theiss B. (red.). Pokój z dziećmi. Pedagogika chrześcijańska wobec zagrożeń rozwoju dziecka. Warszawa: Wydawnictwo Akademickie Żak.

Madre P. (2005). Zranienie życia. Odrodzić się w swej tożsamości. Warszawa: Wydawnictwo Księży Marianów.

Marynowicz-Hetka E. (2009). Pomoc w rozwoju, towarzyszenie społeczne, próg zagrożenia rozwoju - wymiar profilaktyczny. W: taż (red.). Pedagogika społeczna. Podręcznik akademicki, t. 1. Warszawa: Wydawnictwo Naukowe PWN.

Montessori M. (2009). Czym jest wychowanie kosmiczne? W: Surma B. (red.). Pedagogika Marii Montessori w Polsce i na świecie. Łódź-Kraków: Ignatianum.

Olbrycht K. (1999). Rola pedagogów w tworzeniu sytuacji pokojowego rozwoju dziecka. W: Smolińska-Theiss B. (red.). Pokój z dziećmi. Pedagogika chrześcijańska wobec zagrożeń rozwoju dziecka. Warszawa: Wydawnictwo Akademickie Żak.

Pałyga J. (1998). Rwanda. Czas apokalipsy - czas nadziei. Ząbki: Apostolicum.

Petrykiewicz E. (2004). Mayibobo. Dzień z życia rwandyjskiego dziecka ulicy. „Posyłam Was”, nr 3, s. 5.

Piejka A. (2015). Kształtowanie kultury pokoju w ludziach-perspektywa globalna. „Pedagogika Społeczna”, nr 1 (55), s. 115-128.

Półturzycki, J. (2003). Pokój jako naczelna wartość w aksjologii edukacyjnej. W: Mroczkowski I., Wesołowska E. A. (red.). Pokój-dialog-edukacja, materiały z sympozjum naukowego w Płocku, Płock: Novum.

Radlińska H. (1961). Pedagogika społeczna. Wrocław-Warszawa-Kraków: Zakład Narodowy im. Ossolińskich.

Rusinek R. (2003). Dzieci Rwandy. Ząbki: Apostolicum.

Smith S. (2003). Négrologie. Pourquoi l'Afrique meurt? Calmann-Lévy.

Smolińska-Theiss B. (1999). Pedagogika pokoju. W: Smolińska-Theiss B. (red.). Pokój z dziećmi. Pedagogika chrześcijańska wobec zagrożeń rozwoju dziecka. Warszawa: Wydawnictwo Akademickie Żak.

Szczodrowski R. (2007). Problem dzieci bez imienia $w$ obliczu milenijnych celów rozwoju. W: Różański J. (red.). Dzieci głodujące i bez imienia. Warszawa: Wydawnictwo Papieskich Dzieł Misyjnych.

Theiss W. (1996). Zniewolone dzieciństwo. Socjalizacja w skrajnych warunkach społeczno-politycznych. Warszawa: Wydawnictwo Akademickie Żak. 
Theiss W. (1999). Co to jest zniewolone dzieciństwo? W: Smolińska-Theiss B. (red.). Pokój z dziećmi. Pedagogika chrześcijańska wobec zagrożeń rozwoju dziecka. Warszawa: Wydawnictwo Akademickie Żak.

Theiss W. (200o). Ryszard Wroczyński - pedagog społeczny. W: Przecławska A., Theiss W. Pedagogika społeczna. Pytania o XXI wiek. Warszawa: Wydawnictwo Akademickie Żak.

UNESCO (2002). The culture of peace. Paryż: Wydawnictwo UNICEF.

Uniewska A. (2003). „Gen pokoju” - czyli propozycja współczesnego wychowania do pokoju W: Wilk J. (red). Społeczna troska o dziecko w XX wieku. Lublin: Wydawnictwo KUL.

Wojtyła K. (1969). Osoba i czyn. Kraków: Polskie Towarzystwo Teologiczne, dostępny na: http://www.unesco.pl (otwarty: 16.02.2017).

\title{
THE IDEA OF EDUCATION FOR PEACE IN AID PROGRAMS FOR CHILDREN IN AFRICA
}

\begin{abstract}
Humanity has been afflicted by all kinds of disputes, conflicts, wars for centuries. The modern world is also not free from various pressures that often swell to the point where they turn into open armed conflict. Human life, its development and the fate of civilization depends on strengthening and safeguarding world peace. In this context, particular importance is peace education, or education for peace, mutual understanding and respect for the dignity of every human being. The biggest victims of the war are always children and it is they who need special assistance and support in development. Targeted to them aid programs should include the idea of education for peace, so that they shape the young generation in the attitude of: respect for others, the value of life, altruism, empathy.
\end{abstract}

Keywords: peace, peace education, education for peace, genocide, development aid.

Zbigniew Babicki - doktor nauk społecznych w zakresie pedagogiki, adiunkt na Wydziale Nauk Pedagogicznych Uniwersytetu Kardynała Stefana Wyszyńskiego w Warszawie w Katedrze Pedagogiki Społecznej i Pedagogiki Pracy. Swoimi zainteresowaniami naukowymi obejmuje takie subdyscypliny pedagogiczne, jak: pedagogika społeczna i pedagogika opiekuńcza. Adres e-mailowy: z.babicki@uksw.edu.pl. 